\title{
TOWARDS A NEW TOURISM APPROACH: BAFA (LATMOS) GEOTOURISM AREA
}

Yeni Bir Turizm Yaklaşımına Doğru: Bafa (Latmos) Jeoturizm Alanı

Bekir DERINÖZ*

\section{ABSTRACT}

When required by the tourism value of natural and cultural resources evaluated in terms of Turkey has significant advantages. These advantages of the country have not been used sufficiently until today and mass tourism has generally dominated. Geotourism, which emerged at the end of the 20th century, is important in terms of using these advantages and coming to the fore in the world market. Bafa Lake and the surrounding area (Latmos Heraklia) is one of these advantageous areas in Turkey. Aim of the study in southwest Turkey, in Muğla province of the located Bafa Lake and its surroundings, including to identify geotourism resource values, to determine how it can be used in the context geotourism these values and to discuss the existing problems in this regard. For this purpose, literature studies on both the field and the subject were carried out, and field studies lasting 3 years were carried out at intervals in the field. Research has shown that findings obtained at the end of Bafa Lake and the surrounding area has scarce resource values of geotourism in Turkey. The geological and geomorphological structure of the area creates an extraordinary appearance, making the area quite unique in terms of geotourism. This geographical character of the area can be strengthened with the locality element and the sense of place, and the area can be transformed into a geotourism destination. The historical past of the area is as rich and diverse as its geological history. Even in antiquity, the world-renowned area has given many historical and cultural heritage as a present. This heritage is intertwined with the geological structure of the region and has a unique character. Geotourism represents an approach that the area needs in terms of maintaining and preserving this character.

Keywords: geotourism, geoheritage, Bafa Lake, Latmos Herakleia, Muğla.

öz

Turizmin ihtiyaç duyduğu doğal ve kültürel kaynak değerleri açısından değerlendirildiğinde Türkiye önemli avantajlara sahiptir. Bu avantajlar günümüze değin yeterince kullanılamamış, uygulamada genellikle kitle turizmi hâkim olmuştur. 20. yüzyılın sonlarında ortaya çıkan jeoturizm söz konusu avantajların kullanılması ve dünya

\footnotetext{
* Dr., Balıkesir University, Faculty of Arts and Sciences, Department of Geography, Balıkesir/ Turkey, E-mail: bekirderinoz@balikesir.edu.tr. ORCID ID: 0000-0002-0427-2092. 
pazarında öne çıkması açısından önemlidir. Bafa Gölü ve çevresi (Latmos Herakleia) Türkiye'deki bu avantajlı alanlardan biridir. Çalışmanın amacı Türkiye'nin güneybatısında Muğla ili sınırları dâhilinde bulunan Bafa Gölü ve çevresinin jeoturizm kaynak değerlerini tespit etmek, bu değerlerin jeoturizm kapsamında nasıl kullanılabileceğini belirlemek ve bu konuda var olan sorunları tartışmaktır. Bu amaçla hem alan hem de konu ile ilgili literatür çalışması yapılmış, alanda aralıklarla 3 yıl süren arazi çalışmaları gerçekleştirilmiştir. Araştırma sonunda elde edilen bulgular göstermiştir ki Bafa Gölü ve çevresi Türkiye'de az bulunur jeoturizm kaynak değerlerine sahiptir. Alanın jeolojik ve jeomorfolojik yapısı sıra dışı bir görünüm oluşturmakta, alanı jeoturizm konusunda oldukça özgün kılmaktadır. Alandaki bu coğrafi karakter yerellik unsuru ve yer duygusu ile güçlendirilerek alan bir jeoturizm destinasyonu haline dönüştürülebilir. Alanın jeolojik geçmişi kadar tarihi geçmişi de zengin ve çeşitlidir. Antik dönemde dahi dünyaca bilinen alan günümüze çok sayıda tarihi ve kültürel mirası hediye etmiştir. Bu miras yörenin jeolojik yapısı ile iç içe geçmiş ve kendine has bir karaktere bürünmüş durumdadır. Jeoturizm bu karakterin sürdürülmesi ve korunması noktasında esasen alanın ihtiyaç duyduğu bir yaklaşımı temsil etmektedir.

Anahtar Sözcükler: jeoturizm, jeomiras, Bafa Gölü, Latmos, Muğla.

\section{Introduction}

Today, the importance of the tourism sector, which is one of the most important elements of the service sector throughout the world, is gradually increasing. The socio-economic contribution of tourism and its positive effect on other sectors are emerging. Its benefits are felt not only on a global scale, but also on a national scale. Tourism, which was previously limited to coastal tourism, has diversified with the emergence of new tourism approaches. In this diversity, the perception of "sustainability and heritage" has gained importance in tourism in a globalizing world (Dowling, 2013; Farsani and others, 2012; Hose, 1995, 2000, 2005, 2008). Both the countryspecific status of heritage elements, the understanding (responsibility) of transmitting (sustainability) to future generations, and the presentation of this heritage as a worldwide indicator of development and status have gained importance for countries and nations. This heritage has taken its place in tourism in two groups as natural and cultural heritage. Later, in order to transfer this heritage to future generations and preserve its original value, the protection of heritage sites came to the fore. Natural heritage sites have brought together the concepts of "geoheritage" and their preservation "geoprotection". After this stage, the understanding that geoprotection areas should be included in tourism, highlighting both the edu- 
cational and aesthetic value of the relevant geological unit and thus drawing attention to the relevant geological formation has emerged. This understanding has shifted from different tourism types such as ecotourism, wildlife tourism, religious tourism, culture and heritage tourism, museums and monuments, city tourism, adventure tourism, festivals and events, to geology and landscape in the light of research in tourism in the recent past. It has led to a shift towards geotourism, which focuses especially on the natural and human environment, envisages the utilization of geosites, promotes the conservation of geodiversity and an easier and more entertaining understanding of earth sciences. At this stage, at the end of the 20th century, the geotourism approach emerged as a global phenomenon representing a different sub-sector of natural area tourism (also referred to as wildlife tourism in some sources), closely linked to "geological" tourism within sustainable tourism.

Geotourism is part of nature tourism where the main factor is geology and geodiversity (Hose, 1995). This piece has new features and values that accommodate not only the general trends of tourism, but also its own trends. Geotourism as tourism, which mainly focuses on geology, especially emphasizing rural areas and geoparks (Kavecic and Peljhan, 2010), started to develop from the beginning of the 21st century with the emergence of geoparks. However, concerns about the growth of geotourism, its impact on nature conservation and geo exploitation (Hose, 2008) are still controversial due to limited research and also limited assessments. However, geotourism is accepted as a niche (Hose, 2005) or a form of "special interest tourism" in the growing tourism market in the world. Geoparks, which are closely related to geotourism, stand out as the first places that come to mind in terms of geotourism and as examples of sustainable local development. Geotourism also aims to create a consciousness on the scale of geological heritage. In geotourism, geological processes should be approached with a sense of place accompanied by scientific and educational interest, aesthetics and monumentality, as well as a humanistic approach. As a matter of fact, this sense of place is a pioneer of belonging and identity that can only be understood through phenomenology and give originality to the place (Tuan, 1977; Koç and others, 2019; Derinöz, 2021b). With this relationship, geotourism areas can become geosites/geotourism areas with touristic potential. Thus, in geotourism not only geodiversity and geo conservation are promoted, but also the sense of place can be used as a good tool for sustainable development. 
Muğla in Turkey and which has the world's leading destinations, which attract millions of tourists over the years. Considering the number of foreign tourists in the tourism sector, Muğla has a position in the top 3. It maintains the same position in domestic tourism activities. In this sense, geotourism can be used as an important alternative tourism approach and regional development tool for Muğla. It is possible to develop geotourism in the field, to find new methodologies and discuss them, to identify potential geotourism and geopark areas and to open these areas to exploration as high quality places for alternative sustainable tourism. At the same time, recent developments in conservation and development of natural heritage can be encouraged in the field. Geotourism activities in the area, operation and management of potential geopark areas will undoubtedly support local development in the area.

The aim of this study is to determine the geotourism resource values of Bafa Lake and its surroundings within the borders of Muğla province, to determine the usage possibilities of these values and to present the area as a target in terms of geotourism activities. For this purpose, a wide literature review was made in the field at the beginning, field studies lasting 3 years were carried out at intervals. In these studies, the local people living in the area were interviewed, the participant observation method was studied and interviews consisting of open-ended questions were conducted with the local people. In order to reveal the invisible face of geotourism activities in the field, a phenomenological perspective has been followed in order to realize a factual and holistic study. Although applying this method is timeconsuming, tiring and economically troublesome, it has provided significant advantages in terms of reflecting the results in a holistic manner. Tourism in Turkey (especially geotourism) of this point in the study was generally taken into account that it is not preferred; operation carries a unique value for the monitored perspective corresponds to a gap in the literature. The ancient name of the region is known as Latmos Herakleia and this name is used more frequently in the literature. For this reason, it was preferred to use the name "Latmos (Herakleia)" rather than the name "Bafa" in studies on the field, due to the importance of the field in the international literature.

\section{Research Area and Boundaries}

The area named as Heraklia of Latmos (Latin: Latmus; Ancient Greek: $\mu \tau \mu \mathrm{s})$ is a part of the ancient Caria bearing the traces of the Hellenistic lo- 
nian period, covering the Muğla and Aydın provinces of a valley extending in the east-west direction on the northern coast of Muğla province (Figure 1).

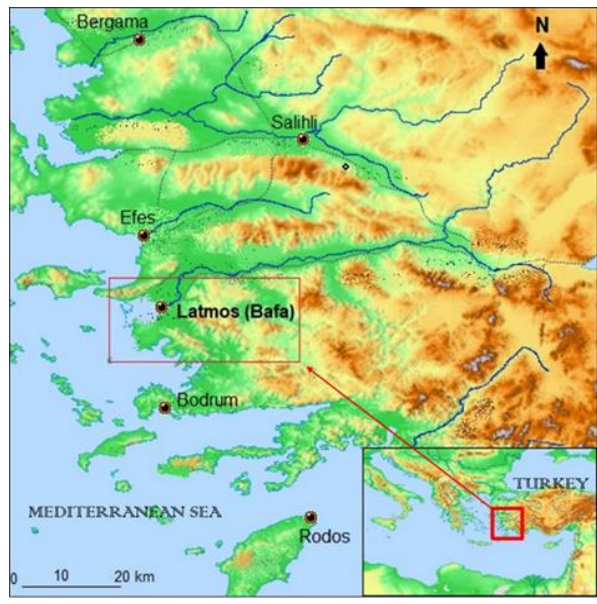

Figure 1. Location of Heraklia of Latmos Geotourism Area (modified from URL-1).

Latmos region, located $25 \mathrm{~km}$ east of Miletus, included Latmos city established on the southern slopes of Latmos Mountain and Latmos Port recorded by Strabon -also Strabon Latmos' Phthires in Troy It also states that it is connected with the mountain- (Joseph, 2006; Konuk, 1997). This area was examined by the Conservation Boards operating under the Ministry of Culture and Tourism between 1952-1985. At the beginning of the 1980s, the area was first tried to gain a large-scale protection status, but this was not successful (Kocalar, 2018, 2020).

Latmos Geotourism site in southwest Turkey, east of the ancient city of Miletus is located at the intersection of the province of Muğla and Aydin. Most of the areas where geotourism resource values are located in the area are within the borders of the province of Muğla. The boundaries of the area are determined on a basin basis. The area covers an area of approximately 18 thousand ha and altitude values vary between 2 and 1400 meters. While the northeastern and eastern parts of the area where the height is minimized in the northwest and southeast are surrounded by mountainous masses, there are hilly areas and Ilbıra Mountain in the south. The Latmos (Beşparmak Mountains) Mountains located in the northeast and east are the highest point of the area with their 1400-meter summit.

The research area is closely related with the ancient cities in Western Anatolia. As a matter of fact, Ephesus (Selçuk), Tralles, Milet, Magnesia and 
Priene in the north of the area; to the south are Halikarnassos (Bodrum) and Knidos ancient cities. There are ruins showing that there have been transportation and trade routes between the study area and these ancient cities since the past. Namely, it was recorded in the records that olive oil and wheat trade was made between Ephesus and Latmos, and Latmos Port was one of the most important ports of the region before being filled by the Menderes River (Peschlow, 2011).

\section{Literature Analysis}

Geotourism entered the world tourism literature in the 1990s. Australia and Europe have been the places where the first studies on this field have emerged. Conceptually, it was defined earlier in Europe, the USA and Australia. These areas were followed by studies conducted in Asia and North America. The term geotourism has been used since the early 1990s, but the origin of the term dates back to the $17^{\text {th }}$ century. Geotourism, which has social, historical, cultural, industrial and archaeological foundations, is still undergoing a process of redefinition and improvement worldwide. The geotourism literature in the world has expanded today and the literature is getting richer with new studies every day. Geotourism is a new approach to tourism with serious growth potential when considered among other types of tourism. Geotourism represents an internationally developing rural development area with academic, economic and sustainable characteristics.

Newsome and Dowling (2010) proposed one of the most frequently used definitions of geotourism. This definition sees geotourism as a type of nature tourism, focusing particularly on geology and scenery. This definition promotes the conservation of geosites, tourism and geodiversity, while at the same time emphasizing the learning of the earth sciences. Dowling $(2010,2013)$ also states that the geological definition sees geotourism as a type or form of tourism, whereas the geographical definition sees it more as a sustainable tourism approach. According to Dowling, these two perspectives are not mutually exclusive. Dowling also argues that these two perspectives should be combined within the concept of geotourism. This situation is also in line with the principles of geotourism prepared by Newsome and Dowling (2010) on the basis of ecotourism principles.

Dowling (2013) emphasizes that knowledge of geology is essential for a full understanding of the geological processes occurring in a particular area or region. Therefore, according to him, geotourism includes cultural components such as abiotic components (such as geology and climate), 
biotic components (such as flora and fauna) and people's lifestyle. Therefore, when developing a new geotourism goal, it is essential to gather and disseminate information about the geographical heritage and its implications on other aspects of an area. When viewed within this framework, it is seen that the definitions of geotourism approach each other and the sustainability of the activity is emphasized as a vital element of the concept today.

An important tool facilitating the development of sustainable geotourism is the use of geoparks, defined by UNESCO as "geographical areas where geological heritage sites are part of a holistic concept of conservation, education and sustainable development." Although the concept of geoparks already existed in the late 1980s, thanks to the active cooperation between the European Geoparks Network (EGN) and UNESCO, geoparks quickly gained importance. This resulted in the creation of the Global Geoparks Network (GGN) in 2004 (Henriques and Brilha, 2017; McKeever and others, 2010; Zouros, 2010; URL-4). Today, there are a total of 161 geoparks in 44 countries and this number is increasing rapidly (URL-2). In addition, some countries have national geopark networks in parallel with their GGN memberships (Henriques and Brilha, 2017). Considering that defining the geographical heritage of each area is a necessary step for the establishment of geoparks and the development of geotourism (Farsani and others, 2012, 2014; Grant, 2010), there are many geosites and geosites with varying levels of geo-heritage value and geotourism potential around the world. It is seen that the geomorphosis has been defined. The number of studies on geotourism is gradually increasing.

The geotourism literature in Turkey is quite limited compared with the world. Geotourism panel discussion on the last 10 years in Turkey, conferences, symposia and lectures are available in the style of local awarenessraising efforts and initiatives, but geographically comprehensive academic study published in this regard is not yet available. Existing studies are mostly in the nature of articles, theses, papers, book chapters and reports (Derinöz 2011, 2014a, 2014b, 2016, 2021a, 2021b). There are various studies, geosite inventory records and lists conducted by MTA (Mineral Research and Exploration) and JEMIRKO (Geological Heritage Research and Protection Association). The Ankara-Çamlıdere Fossil Forest Geopark project work continues.

Geological engineering discipline has dealt with the first issue in Turkey. Kula related to Turkey's application for candidacy in 2010, in 2012, it 
resulted in Italy and Greece, with operations in the relevant Prof. Dr. Work has begun to establish a geopark in Kula under the consultancy of Nicholas Zouros. The results of these studies in 2013 and Turkey established the world's first official geopark $99^{\text {th }}$ visitor center was opened in Kula and services. In this way, it has been included in the UNESCO list for the first time in Turkey's history in the field. Kula Municipality, which participated in the European Geoparks Conference held on 5 September 2013 for the $12^{\text {th }}$ time, officially received the International Geopark Quality Certificate and thus, Kula Volcanic Geopark became the $58^{\text {th }}$ member of the European Geoparks and the $96^{\text {th }}$ member of the UNESCO Global Geoparks Network. Turkey's first and has earned the title of being the only geopark.

When the literature is evaluated in general, it is seen that geotourism studies mostly consist of studies covering approximately 60 countries around the world. These studies are also important in terms of showing a global distribution. It is seen that the studies conducted in the relevant countries focus on the identification and evaluation of the geotourism potential of the areas in question, as well as the geographical heritage of the area. Other common research topics related to geotourism were found to include geoparks, geopark management and planning, geotourism and geological heritage management, new geosite/geomorphosis assessment models, and other methodological approaches (Ólafsdóttir and Tverijonaite, 2018). It is reflected in the literature that researchers are less concerned with geotourism stakeholders at the level of tourists and local communities, and that quite a few studies have examined in relation to geotourism in the context of sustainable development (Figure 2).

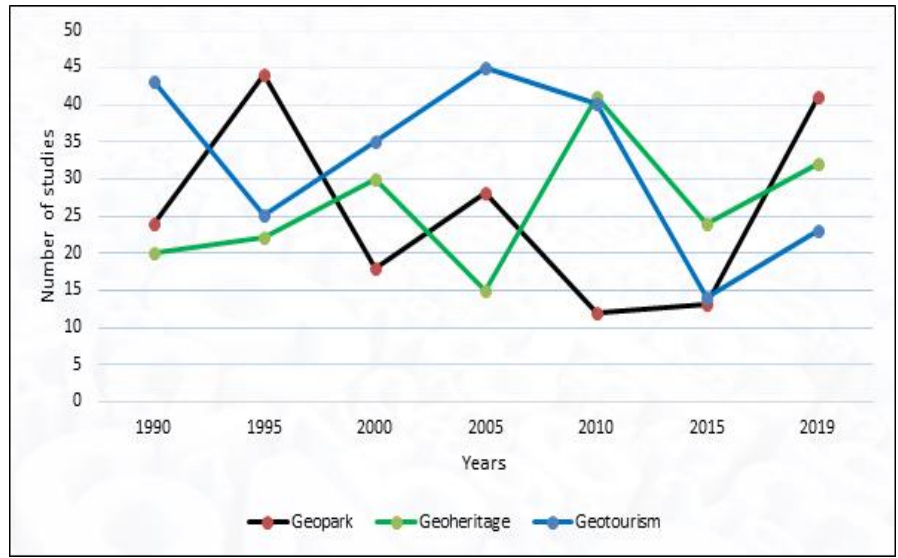

Figure 2. Distribution of the subjects studied in the geotourism literature (1990-2019). 


\section{General Physical and Human Geography Characteristics of the Field}

When evaluated in terms of general physical features, the area has the characteristic of a depression formed as a result of the collapse of the Büyük Menderes massif as a result of tectonic effects. While the base of the Büyük Menderes gutter collapsed, the areas in the north and south rose in the form of mountains. These mountains are Samsun and Beşparmak Mountains. A similar situation was experienced during the first turns of the 4th geological time in the area and the collapsed Büyük Menderes groove deepened (Dora and others, 2005; Brinkman, 1967).

The mouth of the Latmos Bay began to be filled with the alluvium of the Büyük Menderes (ancient name Maeander) river, which poured into the area in classical antiquity. In 300 AD years Bafa Lake started to become a swampy area. The salinity of the area started to decrease gradually and in the following period, it started to become a completely fresh water lake, except that the channels connected to the Aegean Sea brought salty elements. However, today the ecology of the lake is changing and the lake water continues to become brackish water. In addition, the lake has become an important shelter for birds. Especially during the migration period, the lake hosts many bird species. In this sense, the lake has an important potential in terms of bird watching tourism. The lake has the character of an alluvial embankment lake and its depth is at most 25 meters. Due to its basic character, the lake lies on the hollow base to the west of the Latmos Mountain with an area of 60 square kilometers. The height of the lake is around 2 meters above sea level. The widest part of the lake is $6 \mathrm{~km}$ long. Although the area was an important port in the region (Latmos Bay) in the ancient period, it lost this feature over time. The town of Herakleia (Latmos town), which still has ancient features today, continues its existence by shrinking in the area where Kapıkırı Village is located (Kocalar, 2018, 2020; Joseph, 2006).

When the climatic characteristics of the area are examined, a $2^{\text {nd }}$ type Mediterranean Climate (Aegean type Mediterranean Climate) is generally seen in the area. In this climate type, summers are hot and dry, winters are warm and rainy. Rainfall generally falls in the form of rain, the number of days with snow and frost does not exceed 20 days a year. The hottest months are July and August. The coldest months are December and January. The precipitation characteristics of the area are closely related to the climate. Rainfall usually falls in the form of rain. The rainy season is winter. 
The rainiest month is January and the average of the rainy month is 600 $\mathrm{mm}$. The driest period is summer (MGM, 2017).

The vegetation cover of the area is directly related to precipitation and temperature. In general, maquis are seen in the area. The maquis adapted to the field due to the climatic characteristics of the area, deciduous but preserving its existence in summer and winter; it is a type of vegetation that has vegetative activities throughout the year. Maquis is seen as secondary in the area. Primary vegetation of the area is Red Pine (Pinus brutia). In areas where red pines have been destroyed, scrubs have settled as the secondary vegetation in areas up to an altitude of about 700 meters. The main vegetation elements seen in the area are Olive (Olea europaea), Wild Olive (Olea oleaster), Kermes Oak (Quercus coccifera), Oleander (Nerium oleander), Chaste (Vitex agnus-castus), Maple (Phillyrea latifolia), Carob (Ceratonia siliqua), Sandal (Arbutus unedo), Almond (Prunus dulcis), Juniper (Juniperus communis), Red Pine (Pinus brutia), Cypress (Cupressus sempervirens), Laurel (Laurus nobilis) and Blackberry (Prunus laurocerasus) (Öz, 2014).

When the soil structure characteristics of the area are examined, it is seen that brown forest soils are dominant in the area. In the areas where volcanic bedrock is located to the east and north of Bafa Lake, arenas emerging from the fragmentation of granite from volcanic rocks can be seen. These areas create extremely suitable environments for the growth of pistachio pine. Alluvial soils are common in the area to the west of Lake Bafa. These lands are very fertile soils that emerged as a result of filling a river valley, which has been a civilization area since $1000 \mathrm{BC}$, with alluvium over thousands of years. This productivity has been effective in choosing the area as a residential area for thousands of years (Öz, 2014).

When the area is evaluated in terms of population characteristics, it is seen that the rural and urban population of the area has changed significantly from past to present. The population in the area is dispersed in the city center of Milas and the villages connected to this center. About $0.18 \%$ of Turkey's population in the hosting area, including Muğla province ranks 3rd in terms of the amount of the population. When the Muğla province is evaluated in terms of its population, approximately $15 \%$ of the Muğla population lives in the area (Kapluhan, 2014).

The economy of the area is based on agriculture and animal husbandry. In addition, the ancient cities and archaeological sites in the area are 
effective in providing tourism dynamism in the area. Carpets and rugs, which are handcrafted products in the field, are in demand from the domestic and foreign markets. Produced in the villages in the area, Milas carpets have gained a worldwide branded local value. Today, Turkmen and Yoruk origin families, who are settled in the region, carry out carpet and rug works.

\section{General Geological and Geomorphological Features of the Area}

The base of the area is formed by metamorphic rocks belonging to the Menderes massif and intermediate Permian aged formations, upper Permian-lower Triassic aged Bafa formation; Miocene aged Soke formation and upper cretaceous Bozdag formation (Akat, 1980; Graciansky, 1965; Brinkmann, 1967). The Menderes massif is mainly composed of upper Permian metamorphic and upper Oligocene gneisses.

The rocks up to the surface in the area have turned into a folded and fractured structure as a result of tectonic movements. This situation is also observed in Beşparmak eyed (porous) gneisses. Stratification in these rocks is not seen much except in a few areas. Because most of the rocks have lost most of their primary structure and properties. Even in large areas these rocks have recrystallized. Even metamorphic rocks have gained the feature of foliation (schistosity) in most of the region. This situation is related to the increase of deformation in rocks. Sometimes this foliation can be seen symmetrically in Beşparmak eyed (porous) gneisses (Akat, 1980; Graciansky, 1965).

Eyed gneisses differ from other gneisses in terms of content and grain size. Eyed gneisses contain biotite, muscovite, feldspar and micas. The proportion of light-colored materials in meshed gneisses is equal to or less than dark-colored material. Apart from augen gneisses, there are marbles containing quartzchists and sandstone in the area. Transitions between these rocks are compatible (Akat, 1980; Graciansky, 1965).

The age of the folds that shape the rocks in the area and give them character decreases from north to south and from east to west. The gneiss masses in the area were folded together with the schists, together with the folds resulting from tectonic movements in the north-south direction. During this folding, massive masses were subjected to fractures in some places, and in some places they were stratified at an angle with these fractures. This structure can be easily distinguished in the area where the best examples of schistosity are found (Figure 3 ). 


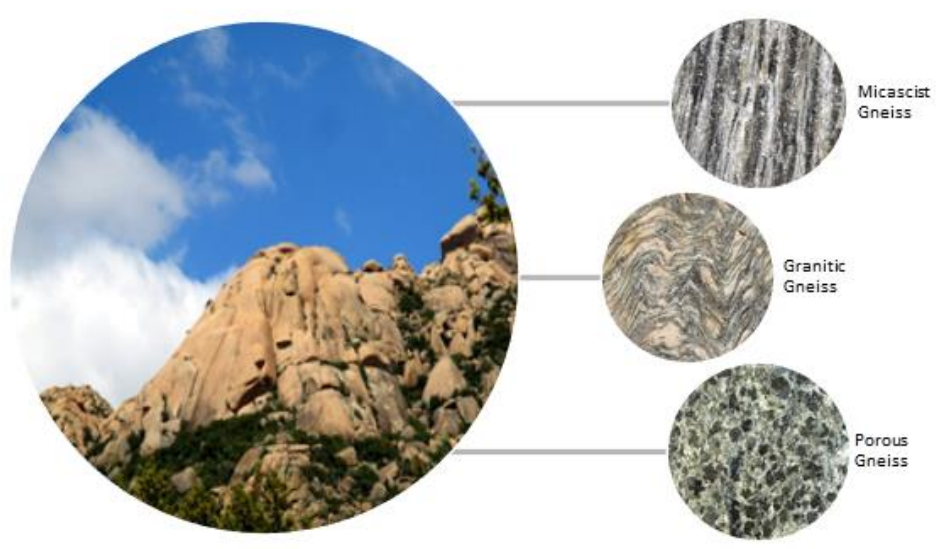

Figure 3. The geological diversity of the Latmos (Bafa) Geotourism Area, the geological material undergoing different stages of formation, the fragmented structure in the area and the geological-geomorphological appearance that emerges from the erosion of this structure by external forces offers important geotourism advantages to the area.

Bafa Lake located in the area is an alluvial embankment lake located in the Büyük Menderes depression basin. The length of the lake, which is close to the Aegean Sea, is approximately $16 \mathrm{~km}$ and its width is approximately $5 \mathrm{~km}$. The lake, which has an average depth of 4-5 meters, is fed by regular floods of the Büyük Menderes River, groundwater and seasonal streams. The area of 3,200 hectares on the edge was taken under protection as Bafa Lake Nature Park on 08.07.1984 by the Ministry of Environment and Forestry, General Directorate of Nature Conservation and National Parks (Kocalar, 2018).

\section{Geotourism Resource Values of the Area}

Latmos Geotourism area has a very rich content in terms of geotourism resource values. The area contains historical sites, ancient marble quarries, prehistoric paintings, Byzantine paintings, rock tombs, reliefs, mushroom rocks, ancient cities and castles, temples and altars. In addition, the peculiar structure of the rocks in the area undergoing schistosis makes the area a unique area that is abundantly fragmented and interesting landforms have been formed.

\subsection{Bafa (Camici) Lake}

Bafa Lake is one of the most important geotourism attractions in the area. There are many geological studies on the formation of the area where 
the lake is located (Graciansky, 1965; Akat, 1980; Kocalar, 2018; Aksoy, 2004, Başarır, 1970; Bozkurt and Park, 1993). The geological studies that have been continuing for 30 years in the study area and its immediate surroundings; upper cretaceous flysch; tertiary terrestrial sediments and surface deposits and locally Miocene volcanic formations (Figure 4).

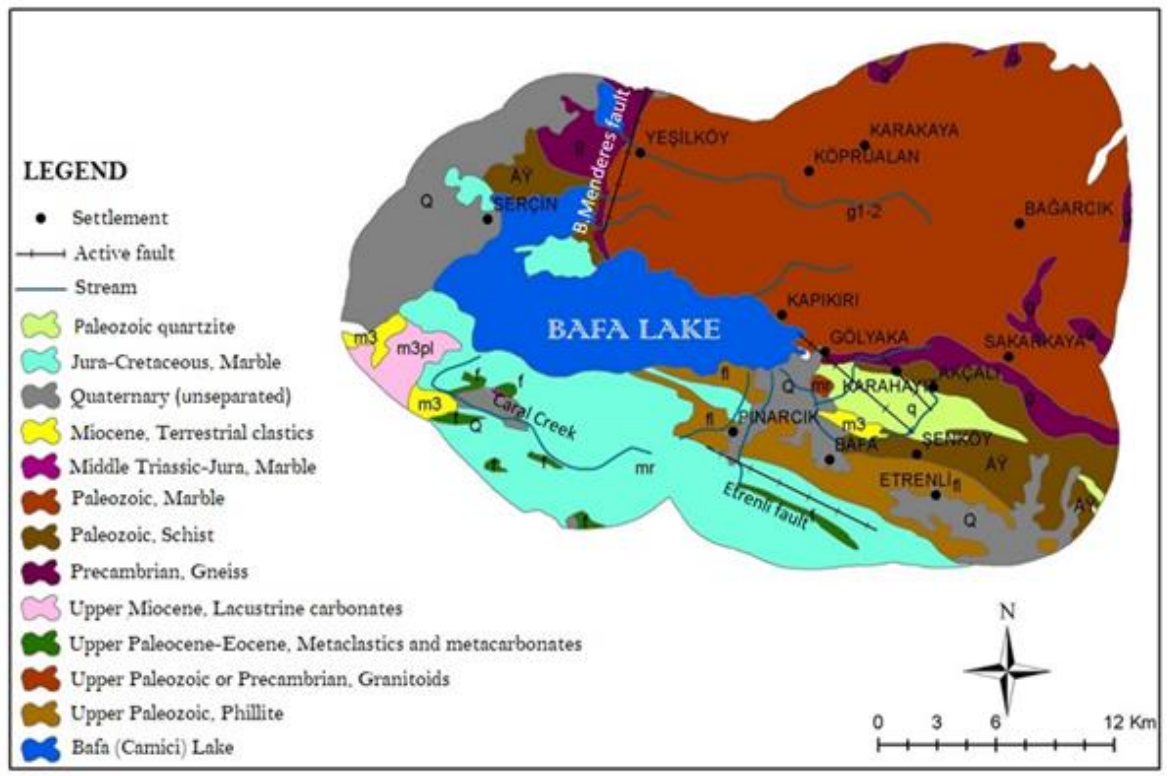

Figure 4. Geology Map of the Latmos Geotourism Area (Source: Akat, 1980 and Graciansky, modified from 1965).

The area where Bafa Lake is located is located in the Western Anatolian Fault Zone. The area where the lake is located in this area shows a tectonic basic feature. On this tectonic base 5-6 AD. In the $16^{\text {th }}$ century, there was the Gulf of Latmos, which is a port city on the Aegean coast and connected to the Aegean Sea, and Latmos city on the edge of this gulf. Latmos, one of the brightest cities of its period, was a city of trade, transportation and warehouse (Peschlow, 2011). Ships departing from the Gulf of Latmos were trading olive oil and wine over the Aegean Sea, and also carried the products obtained from the marble quarries in the north of Latmos City to the ancient cities of the period. However, with the alluviums brought by the Büyük Menderes River in time, the connection of the bay with the sea was disconnected and the connection of Bafa Lake with the sea was formed and the present lake area was formed. With this feature, although the lake is located on a tectonic base, it is in the group of set lakes and has the char- 
acter of an alluvial embankment lake because it is formed as a result of cutting (set) with alluviums (Akkurnaz, 2018).

There are pelitic and basic-ultrabasic rocks metamorphosed during green schist metamorphism in and around the lake. Among these rock types, which are generally called metamorphite, it was determined that there are chlorite schist, sericite schist, quartzite, calcschist, actinolite schist, amphibolite, serpentine, muscovite schist, tremolite schist, biotite schist and garnet schist (Akat, 1980). These rocks, with an estimated age of 200-250 million years, formed extraordinary shapes in and around the lake with the effect of external forces (Photo 1 and 2). There are also some stories about the formation of these shapes among the local people in the field from past to present. These stories, which attribute the fragmentation of rocks to lightning strikes falling from the sky, monsters that lived in the field, and giant snakes that lived in the field, make the area different and attractive both culturally and physically with the shapes they have integrated. This difference and attraction creates a serious potential in terms of utilizing the area within the scope of geotourism by evaluating the area as a whole.
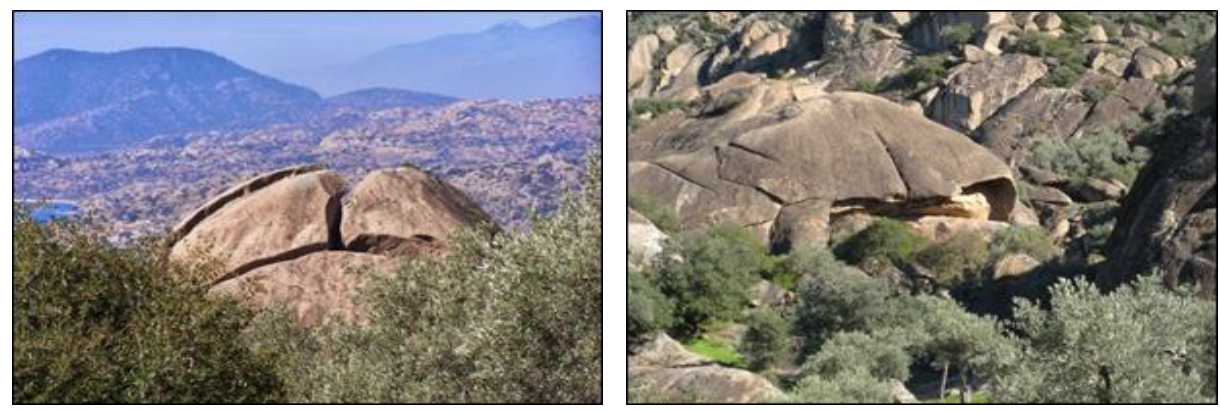

Photo 1-2. A view from the rocks on the edge of Bafa Lake in the Latmos Geotourism Area. These rocks, generally of granite and granadiorite character, were fragmented by the effect of external forces and formed original shapes (Photo: V. Yüksel).

There are 5 islands in Bafa Lake, which were used in ancient times and were built using the geological materials in the area, and which contain some magnificent and sacred places of the period. These islands are Menet Island, Ikiz Island, Kapıkırı Island, Kahveasar Island and Uyuz Island. There are monasteries and defense castles on Menet Island, Ikiz Island, Kapıkırı Island and Kahveasar Island. It is estimated that the buildings were built in the $4-5^{\text {th }}$ centuries AD. It is seen that marble, schist, granite, granodiorite 
and some metamorphic rocks were used in the construction of these structures. It is even seen that some green rocks from the ophiolite group and hard rocks such as marble and quartzite are used to decorate the courtyards and walls of the monastery, sometimes one after the other, and sometimes as voids.

It was also recorded in some sources that marble was brought from Bergama to the area (Akkurnaz, 2018). It is known that the Kingdom of Pergamon had a widespread reputation in marble processing in antiquity and sent processed marble products to many ancient cities, especially the ancient city of Kzykos located around Arteke (Erdek). There is also an opinion that the marble remains found around Latmos were processed by the marble masters who came from there as a result of the relationship with the Kingdom of Pergamon.

\subsection{Mount Latmos (Beşparmak)}

Latmos, also known as Beşparmak Mountains, is located in the northnortheast of Bafa Lake. These mountains are in the West Menteşe mountain range, generally in the east-west direction, on the West Anatolian Fault Line, which are included in the fractured structure system (horst). These mountains have been one of the sacred mountains of Anatolia, which has been called Asia Minor for centuries.
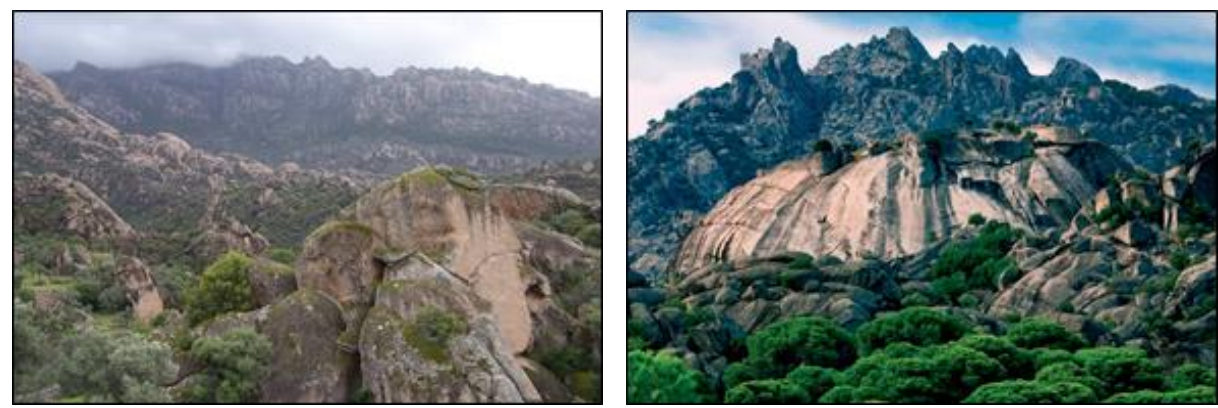

Photos 3-4. A view of the Latmos Mountain (left) and Tekerlektepe (right) geosites located in the Latmos Geotourism Area. The Tekerlektepe Geosite has been accepted as the throne of Zeus and the Gods of Weather and Rain for centuries. It was used for worshiping gods, offering sacrifices and prayers for rain (Photo: A. Demir).

It is known that the area has been a temple and worship area since the Neolithic period. The area was considered as the home of the Weather and Rain Gods in the Neolithic period and these gods were worshiped in the area. The round hill structure, which resembles the wheel shape of the moun- 
tain, caused the mountain to be called the Wheel Mountain and this round hill structure was accepted as the throne of the God of Air in ancient times (Can, 2012). Later, Zeus, who defeated the Weather and Rain Gods, took the throne and sovereignty here (Photo 3 and 4 ).

Since the Neolithic period, the people living in the area built various structures in order to worship and dedicate Zeus. Some of these structures have preserved their existence in the area until today. For example, in the valley to the north of the Latmos Mountains, various stones were planted by the local people living in the area at that time as a symbol of Zeus's greatness. This sacred valley, which was rich in terms of obelisks at that time, was named Dikilitaş Valley in later periods. This valley and the stones erected are in a place where Zeus at the top can easily see when he looks down. Stones in the valley and a Hellenistic Period temple built in the valley were dedicated to God Zeus. This situation is written as "Zeus Akraisoa (to Zeus at the top)" in the upper column head of the temple, which is made of marble. The articles were written by the marble masters of that period in an easily readable and angular manner (Akkurnaz, 2018). Symbols and embroideries symbolizing Zeus are also seen on the marbles.

The mountain continued to be the religious center of rain and other weather events until the Byzantine Period and witnessed various structures and uses. In the Byzantine period, new monasteries were built in the area and the area became a monastery living center. In the $10^{\text {th }}$ century $A D$, there are traces of going up on the mountain in mass groups (processions) and praying for rain during dry periods (Akkurnaz, 2018). It has been found that these groups performed various rituals using the rocks in the area during their prayers and that they carved these exhibited rituals on the surrounding rocks at certain times. The fact that these rocks are generally granite and marble is related to the geological material in the area. However, it is seen that in the buildings built for religious purposes (especially in temples and altars), marble processed in the marble quarries in the area is used.

Although the field is known at national and international level, the importance of the values of the field has begun to be understood and discovered at the end of the 1990s. German archaeologist Kauff, who worked in the field between 1978-81, British geologist Brenny and his friend Scabb, who visited the site in 1988, mentioned the area both in their scientific studies and in their memoirs (Peschlow, 2011). But he was first discovered prehistoric rock paintings in Persclow field archeology department of the University of Berlin from the German Heing Foundation support in 1994 to con- 
duct archaeological studies in Latmos Mountains in Turkey. Later, he published these studies in the German archeology magazine Aktuelle Archaologie Magazine, and the work attracted the attention of the German archeology world. This discovery occurs after a certain awareness at the local level is in this case due to the nature of the decision-making mechanisms in Turkey could not be used in areas such as talents for the benefit of the country reflected the desired level.

\subsection{Kirselik Monastery}

The ruins of the monastery on the Latmos (Beşparmak) Mountain in the north of the area are called Kirselik by locals. This monastery is in the north of Bafa Lake and $3 \mathrm{~km}$ from Kapıkırı Village is located away. The area of the monastery, thought to date from the $5^{\text {th }}$ century $B C$, is approximately 250 square meters. Supported by 12 round arches and 8 columns, the monastery (Akkurnaz, 2018) was established in the place known today as Çakraktepe.

Kirselik Monastery was established on a hill overlooking the area, and it is about $2 \mathrm{~km}$ from the Tekerlek Tepe Geosite, which is accepted as sacred away. The same material was mainly used in the construction of the monastery, which was built on granite blocks with a diameter of 3-5 meters. The granite cut stones, which are mainly used in the monastery walls, are replaced by marble columns in the interior. These marbles are approximately $1 \mathrm{~km}$. It is highly probable that it was brought from the old abandoned marble quarry at a distance.
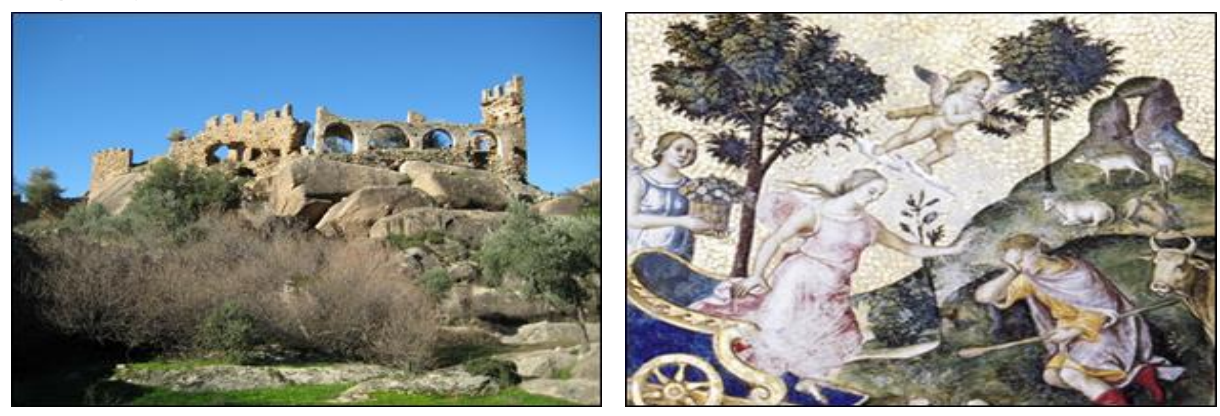

Photos 5-6. A view from the Kirselik Monastery Geosite in the Latmos Geotourism Area (left). Illustration about the field whose missing parts were completed and corrected in the book Archäologische Arbeiten in der Türkei published by Shcren in 1978 in Germany (Shcren, 1978). This illustration (right) is important in terms of giving information about the life of the period in Heraklia of Latmos (URL-3). 
On the inner wall of the monastery, a depiction thought to be from the $6^{\text {th }}$ to $7^{\text {th }}$ century BC was discovered by the German archaeologist Shcren during archaeological research between 1960 and 1972 (Akkurnaz, 2018). Shcren photographed the depiction and made various drawings. Shcren worked in Germany regarding the depiction, which could not preserve its holistic structure due to the demolition and destruction of the monastery walls, and in 1978 he completed the missing and damaged parts with illustrations (Photo 5 and 6) suitable for his period and published in his book Archäologische Arbeiten in der Türkei.

In the illustration, it is reflected that agriculture and animal husbandry is done in the area and that people live in prosperity. In addition, the angel ritual on the top indicates that the area is religiously sacred. The illustration also depicts the rocks in which people walk with their animals and are almost a part of their daily lives (Akkurnaz, 2018). This is important in terms of showing the place and meaning of today's geological elements in people's lives since ancient times. In fact, the appearance of the rocks in the area at that time is depicted in the upper right corner of the illustration. This shows that the geological structure in the area was cared, meaningful, sanctified and worth painting even in those times.

\subsection{Sobran Castle}

Sobran Castle was built on granite ground in a high place overlooking the monastery, 400 meters from Kirselik Monastery in the north of Bafa Lake. The upper part of the castle, which shows a narrow and high building character, has been damaged today (Photo 7). The height of the castle, which has an internal usage area of approximately 40 square meters, is 11 meters. However, the upper parts of the castle have been damaged by both man-made and natural disasters. Granite rocks, which were completely extracted from the region, were used in the construction of the castle. These rocks were processed in ancient quarries, turned into rectangular shaped cut stones and used as building materials. It is estimated that the castle was damaged and repaired in the great earthquake that took place in the $10^{\text {th }}$ century AD. Traces of this were found on the castle floor and walls (Akkurnaz, 2018). It is seen that instead of the damaged granite stones on the east wall of the castle, marble pieces were placed in between. This proves that the castle was repaired by another civilization, using geological materials in the region, long after the construction of the castle. Consisting of building materials suitable for the bedrock, the castle reflects the geocultural past. 


\subsection{Vulture Rock}

There are parts of the lithological structure in the area where there are blocks on top of each other from time to time. One of them is the area where the Vulture Rock is located. A granite block in this area resembles a bird's head when viewed from the side profile as a result of erosion over long periods of time. Local people named this rock "Vulture Rock" because of the Vulgus (Vulgus vulgetstris) birds that used to live in the area (Photo 8).

The width of the Vulture Rock is about 2 meters and its height is around 3 meters. A part resembling a bird's beak was formed as a result of erosion at the southwestern end of the rock. The southern edges of this eroded section have very sharp contours, while the north facing edges have been destroyed. The Vulture Rock Geosite is a shelter where local shepherds frequently visit and take shelter on rainy days. For this reason, various human marks are seen both on the outer surface and on the inner surfaces of the wearing part. There are different narratives in the region regarding the formation of the Vulture Rock Geosite. In addition to the idea that the rock was formed in its natural state where it is located; there is also the idea that it was erected in the name of the gods in ancient times. Both views have a share of truth when other geosites in the region are considered. As a matter of fact, there are marble and granite rocks in the nature of monuments erected in the name of the gods in different parts of the Latmos Mountain.
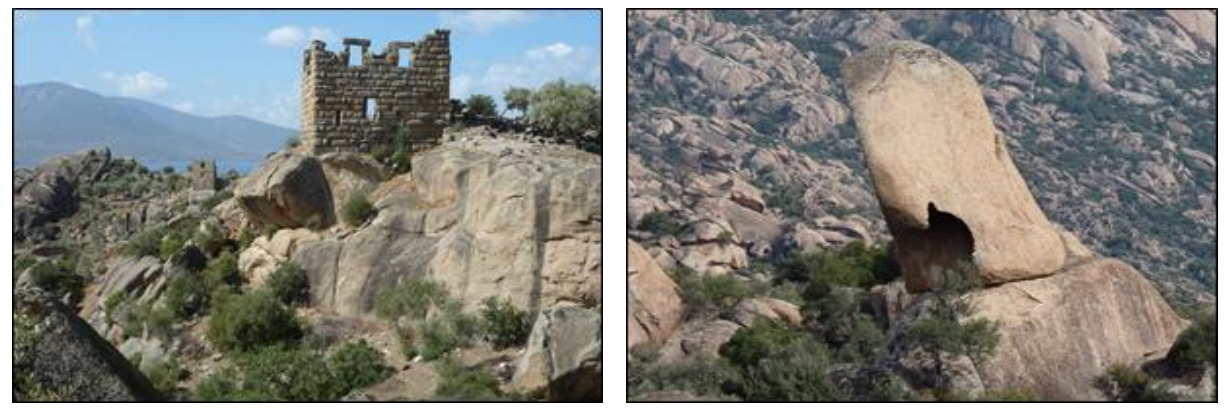

Photo 7-8. A view from Sobran Castle Geosite in Latmos Geotourism Area (7). A view from the Vulture Rock (8) Geosite in the Latmos Geotourism Area.

\subsection{Turtle Rock}

It is located among olive trees on the coastal plain to the east of Bafa Lake. The geosite was basically formed as a result of the fragmentation and erosion of the lower part of a granite block, and a gap of approximately 4 
square meters. The high amount of feldspar and muscovite in the geological structure of the geosite has facilitated the erosion of the geosite (Photo 9).

Geosite is today a shelter where local shepherds take shelter in rainy weather and are used as a canopy in summer heat. Apart from this, it is known that wild animals sometimes function as hiding and nesting areas. The width of the geosite is about 7 meters and its height is around 4 meters.

\subsection{Bagarcık Castle}

Bağarcık Castle is located on the Latmos (Beşparmak) Mountains. The area near Bağarcık Village of Koçarlı District has the feature of being an ancient settlement (Photo 10). The ancient name of the area is not yet known. An ancient stone paved road was found between Bağarcık Castle and Herakleia Ancient City (Akkurnaz, 2018). It is known that this road had a strategic importance at that time and was used in commercial activities.

The castle, which was built on a granite rock mass, provided ease in terms of defense and preserved its existence for centuries due to its steep terrain. The stones used in the construction of the castle were obtained by making use of the geological structure in the field. Archeological studies in the area revealed that the building belongs to the $4^{\text {th }}$ century BC. However, Peschlow stated in his writings that the settlement date of the area goes much earlier than this date. In addition, Peschlow states that the castle was the place of God's presence at that time and that the people of Caria of that period performed religious ceremonies and rituals here (Peschlow, 2011). In addition to the castle, there are many rock tombs in the area. The area, which has hosted civilization for about 8000 years, should be taken under protection and brought into geotourism immediately.
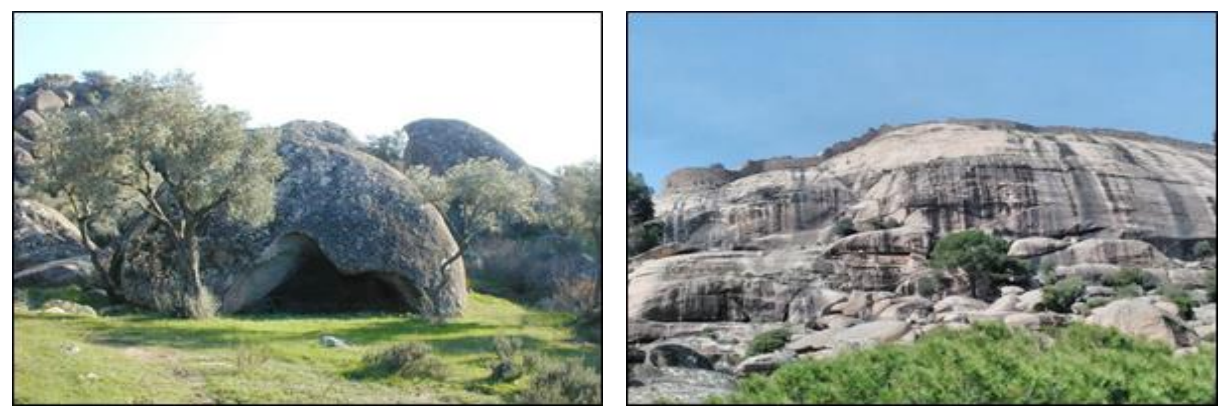

Photo 9-10. A view from the Turtle Rock Geosite (9) in the Latmos Geotourism Area. A view from the Bağarcık Castle Geosite (10) in the Latmos Geotourism Area. 


\subsection{Yediler Monastery}

The monastery, located on the Latmos Mountain, within the boundaries of Milas District, has been a sacred place for Christianity for centuries. Archeological studies in the area revealed that the monastery belongs to the 10th century (Peschlow, 2011). On the walls of the monastery, there are frescoes of the birth, death, blessing and daily life of the Prophet Jesus at that time.

Unfortunately, many of the monastery frescoes are severely damaged today. The destruction continues day by day. The local people notified this situation to the Muğla Cultural Heritage Preservation Board, but no work was initiated by the board. Thereupon, the Non-Governmental Organizations in the region notified the relevant institutions in writing and requested that the area be taken under protection by building a fence or fence around the area. Upon this, it was reported by the Milas Museum Directorate that the relevant protection measures would be taken in the area. However, although 9 years have passed since this application, no protection measures have been taken in the area.

In 2015, the work of building a road to the area where the monastery is located by the Directorate of Survey and Monuments came to the agenda. However, this study was suspended when the local people and nongovernmental organizations protested as it would destroy most of the resource values in the region. The construction of the road considered in this study to the field will cause the irreversible loss of most of the geotourism resource values in the area. For this reason, the relevant study should be canceled and the area should be taken under protection and brought into geotourism.

\subsection{Kapıkırı Village}

Kapıkırı Village is located in the north of Bafa Lake, in the area where the ancient city of Latmos was established. The traces of many civilizations can be seen in the area, whose history goes back to the 2nd century BC. Carians, lonians, Byzantines, Seljuks and Ottomans are among them. This situation enabled Christian and Islamic architectural works to be found together in the area and increased the cultural richness of the area. The area is important in terms of traditional culture, geoculture and geotourism.

Kapıkırı Village was founded on a granite-granadiorite foundation at the foot of the Latmos Mountain. One of the most important reasons for the establishment of the village here is the fact that the volcanic areas are fer- 
tile agricultural lands. As a matter of fact, there are countless examples of this in the world. Volcanic areas are one of the most frequently settled areas in almost every part of the world. Even in many countries with active volcanoes, people often settle near these volcanoes, although they are dangerous. For these reasons, both in ancient times and today, the local people have used this area, which they have settled on, primarily for agriculture and animal husbandry.

In addition, the local people have used the unique geological character of the area in their daily lives. For example, they used the volcanic and metamorphic rocks of the region in the construction of many houses built locally in the area. These houses, which are almost camouflaged on the geological ground in the foundation, are representative of the region with their architectural features (Photo 11 and 12). These traditional houses, which are generally built with 2 or 3 rooms, are based on metamorphic material with a harder feature, while granite is used on the outer walls of the house.

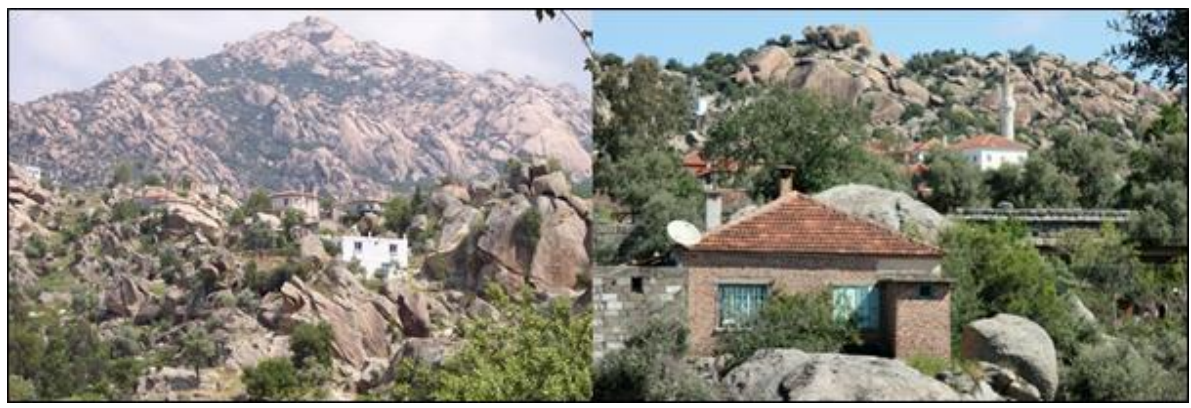

Photo 11-12. A view from the Kapıkırı Village Geosite in the Latmos Geotourism Area. The village itself is in the position of a geosite, as the geological foundation on which the village was established contains many geological-geomorphological formations.

When the area is evaluated in terms of geotourism, there are important structures reflecting the period of Christianity and Islamic Civilizations in the region. These structures include churches, monasteries, mosques, inns and baths, castles, bridges, aqueducts and cisterns. The geological building materials of the region were used in almost all of these buildings and the architectural type unique to the region was developed. These structures are an example of how and how the local people who lived in the region in the past and today use geology and to what extent it reflects on their daily life. In this sense, the geocultural structure of the area is still alive and dis- 
tinct. This geocultural structure is among the indispensable elements for geotourism (Figure 5).

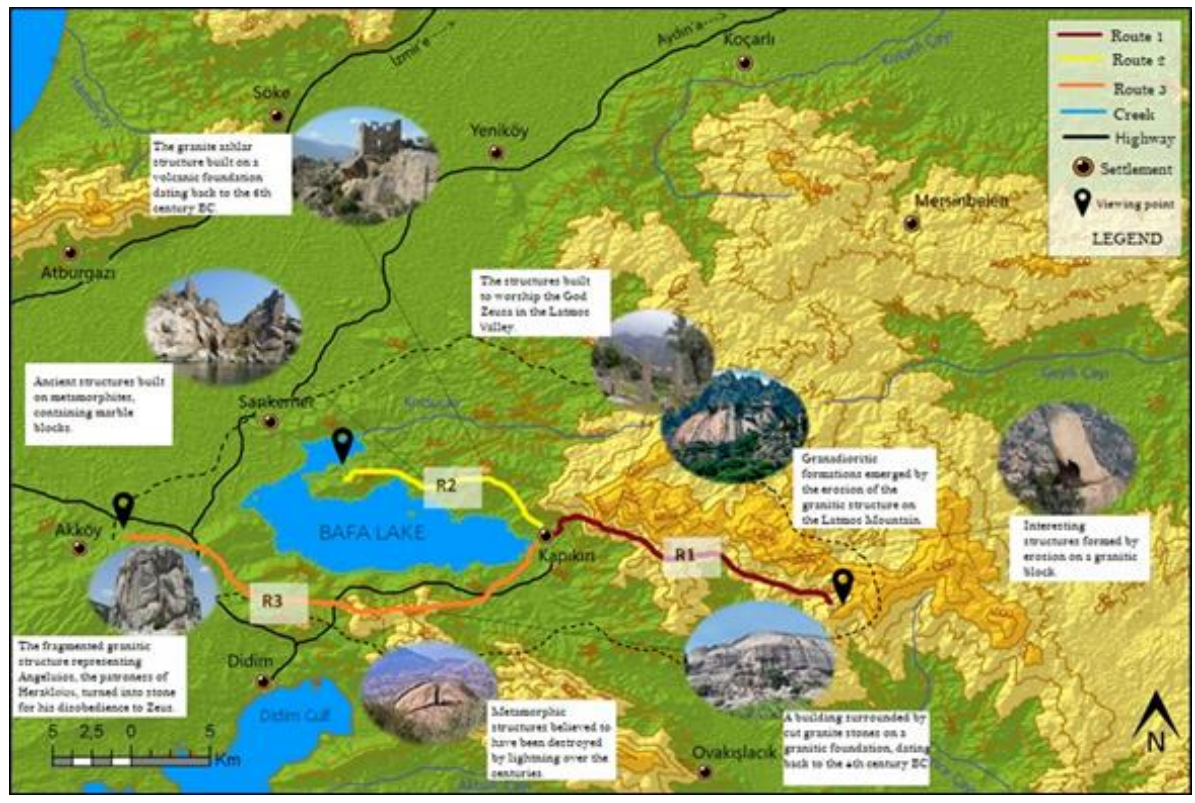

Figure 5. Latmos (Bafa) Geotourism Area geosite map.

\section{Conclusion and Solution Suggestions}

When Bafa Lake and its surroundings are evaluated in terms of the implementation and sustainability of geotourism, the site offers favorable opportunities in terms of geological heritage, holistic protection, education and sustainability concepts. There are many sites designated as protected areas, especially in the south, southeast and east of the area. These areas, which are important in terms of cultural history, are areas that can be evaluated effectively in the context of geotourism. The natural environment of the area, especially the climate and landforms, offers very favorable opportunities for geotourism. The area is an area where human intervention is low in Western Anatolia and still contains partially untouched places, and it is a region where many rare species of fauna and flora are inhabited.

The landform features and landscape supported by the geological foundation in the area constitute the most important resource values of the area. Unfortunately, a holistic protection and management infrastructure has not yet been established for the protection of these resource values. Approximately 7 thousand hectares of area in the southeast of the area was declared as a 2 nd degree protected area in 1984. However, mining activities in the region have violated the boundaries of this area from time to time. 
Tourism is an important activity in the field. However, the tourism potential of the area cannot be fully determined and evaluated due to the lack of any management plan in most regions or due to wrong/incomplete management plans. This situation leads to the emergence of geotourism area losses day by day in the area. As a matter of fact, many sensitive features and values in the area are damaged for this reason, and irreversible geotourism area losses are experienced.

It seems that the study area is suitable for the development of local services for geotourism. In addition, the site is a place where the concepts of site, geological heritage, holistic protection, education and sustainability can be applied within the concept of geotourism. However, there are land problems and disagreements in the area, especially in the west, south and east of Lake Bafa. Due to the occupation of the sites in the southeast of Lake Bafa during agricultural use, serious disputes have occurred between local people and public relatives in the last 20 years. Some of these disputes have been transferred to legal media.

Latmos geotourism area has the characteristic of being a site where the geological structure it has, the natural heritage structure formed by the fragmentation and transformation of this geological structure by external forces and the character of the concept of geological heritage when evaluated in terms of geomorphological character. It is possible to evaluate, use and transfer to future generations the values found as geological heritage in the field together with the concepts of holistic conservation, education and sustainability.

There are no serious problems in terms of accessibility among geotourism resource values in Latmos Geotourism Area. The section where accessibility is the most difficult is the part in the north of Lake Bafa. This area is an area that stands out with its mountainous and rugged character called Beşparmak Mountains. The fragmented granite and gneiss structure of the land makes accessibility difficult in places. There are no serious problems in terms of transportation, except for the hilly region in the north and northeast.

Management problems in the field are still continuing. Turkey in the areas of resource management and living in protected areas should not be included in the study and protection of the local people's ideas thoughts, unfortunately, continues in disease activity Latmos Geotourism site. In this sense, a strict protection has been preferred until recently, especially in the 
part of the area declared as a Nature Park. As a result of this strict protection in these regions, the local people who are engaged in fishing and reed have serious difficulties in making their living. There are even people who are in court with the state due to these problems. As a matter of fact, the information obtained as a result of the interviews conducted in the region shows that the local people in the area have a negative perspective on conservation activities and that the conservation activities carried out with top-down decisions have not been successful in the field. These solid protection activities (Yellowstone type conservation model), which have been abandoned and not applied all over the world, should be abandoned as soon as possible in the field and the "Participatory Natural Resource Management Model" should be implemented in the field, which also takes into account the opinions and suggestions of the local people. This situation is also of vital importance in terms of geotourism activities to be carried out in the area.

There are many ancient cities within the study area. Almost half of these ancient cities have protected areas. This situation paves the way for illegal excavations and treasure hunting activities in these ancient cities. Like this, many illegal activities cause the destruction or damage of geotourism resource values day by day due to lack of protection and planning. These ancient cities, which are within the study area, are very suitable to be evaluated within the scope of geotourism. All of these ancient cities have protected areas. However, despite this protection status, significant archaeological value losses were experienced in the area between 19701990. One of the reasons for this is that the protection and planning activities in the area are insufficient.

Again, the mines and quarries operating near the ancient cities around the area cause significant geotourism area losses, especially in ancient cities. The unwavering use of the resources in the area by the mines and quarries seriously damages the geotourism potential of the area. Almost all of these mines and quarries use significant amounts of explosives to soften and loosen the ground (to reduce their costs) during their operations. These explosives cause the area to lose its geotourism values within minutes within minutes. These activities, which cause irreversible losses in the field, should be stopped and banned immediately. 


\section{References}

Akat, Umur (1980). Menderes Masifi Batısının Jeolojisi. MTA Raporu 6952. Ankara: MTA.

Akkurnaz, Sedat (2018). "Latmos ve Herakleia Yerleşimleri". Aydın'da Bir Dünya Kültür Mirası Latmos. Ed. Engin Akdeniz ve Sedat Akkurnaz. İstanbul: Arkeoloji ve Sanat Yayınları.

Aksoy, Rahmi (2004). "Selimiye (Milas-Muğla) Kuzeyinde Menderes Masifinin Mesoskopik Tektonik Özellikleri”. Selçuk Üniversitesi Mühendislik, Bilim ve Teknoloji Dergisi, 19(2): 61-68.

Başarır, Erol (1970). Bafa Gölü Doğusunda Kalan Menderes Masifi Güney Kanadının Jeoloji ve Petrografisi. Fen Fakültesi ilmi Raporlar Serisi 102. İzmir: Ege Üniversitesi Matbaası.

Bozkurt, Erdin \& Park, R. Graham (1993). "Menderes Massif: A Cordilleran Type Metamorphic Core Complex in Western Turkey". Terra Abstracts, 5: 255.

Brinkmann, Roland (1967). Menderes Masifi'nin Milas-Bodrum-Ören civarındaki Güney Kanadı. Fen Fakültesi ilmi Raporlar Serisi 43. İzmir: Ege Üniversitesi Matbaası.

Can, Şefik (2012). Klasik Yunan Mitolojisi. İstanbul: Ötüken Neşriyat.

Derinöz, Bekir (2011). "A Proposal Area for Geotourism in Western Turkey: Kula". Annual Meeting of the European Association of Geographers, (June 2-5, 2011). Athens, Greece.

Derinöz, Bekir (2014a). "Muğla'da Potansiyel Bir Jeoturizm Alanı: Uyku Vadisi (Milas)". CD 2014 Uluslararası Kongresi Özet Bildirileri (Muğla, 4-6 Haziran 2014). Muğla, 943.

Derinöz, Bekir (2014b). "Muğla'nın Jeoturizm Kaynakları ve Değerlendirilme Olanakları”. VII. Lisansüstü Turizm Öğrencileri Araştırma Kongresi (Aydın, 4-5 Nisan 2014). Ed. Nazmi Kozak ve Ebru Günlü. Ankara: Dokuz Eylül Üniversitesi, 677-678.

Derinöz, Bekir (2016). "Yerel İnanışların Doğa Koruma Üzerindeki Rolü: Kapıkırı Köyü Örneği (Muğla-Türkiye)". CD Uluslararası Yılık Kongresi (Balıkesir, 2-4 Haziran 2016). Balıkesir.

Derinöz, Bekir (2021a). "Maden Ocaklarının Jeoturizm Açısından Değerlendirilmesi: Soma (Manisa) Örneği”. Motif Vakfı Uluslararası Sosyal Bilimler Sempozyumu II Tam Metin Bildirileri. Ed. Mehmet Ali Yolcu ve Mustafa Aça. İstanbul: Motif Vakfı Yayınları, 358-378. 
Derinöz, Bekir (2021b). Muğla'nın Jeoturizm Kaynakları ve Değerlendirilme Olanakları. Doktora Tezi. İzmir: Ege Üniversitesi Sosyal Bilimler Enstitüsü.

Derinöz, Bekir vd. (2017). "Gökgöl Mağarasının (Zonguldak) Jeoturizm Potansiyeli”. I. Uluslararası Demirci Sempozyumu (Manisa, 12-14 Ekim 2017) Bildiriler Kitabı. Ed. Suat Donuk. Manisa, 339-340.

Dora, Özcan vd. (2005). Menderes Masifi Çine Asmasifindeki BafaYatağan-Karacasu Arasında Uzanan Gnays/Şist Dokanağının Niteliği: Jeolojik, Tektonik, Petrolojik ve Jeokronolojik Bir Yaklaşım. TÜBiTAK Projesi, Proje No: 101Y132. Ankara: TÜBiTAK.

Dowling, Ross K. (2010). "Emerging Volcano and Geothermal Related Tourism in Iceland". Volcano and Geothermal Tourism: Sustainable Georesources for Leisure and Recreation. Eds. Patricia Erfurt-Cooper \& Malcolm Cooper. London: Earthscan, 209-220.

Dowling, Ross K. (2013). "Global Geotourism, an Emerging Form of Sustainable Tourism". Czech Journal of Tourism, 2(2): 59-79.

Farsani, Neda T. and ohers (2014). "Geo-knowledge Management and Geoconservation via Geoparks and Geotourism". Geoheritage, 6(3): 185192.

Farsani, Neda T. and others (Eds.) (2012). Geoparks and Geotourism: New Approaches to Sustainability for the $21^{\text {st }}$ Century. Boca Raton, Florida: Brown Walker Press.

Graciansky, Pierre D. (1965). "Menderes Masifinin Güney Kıyısı Boyunca Görülen Metamorfizma Hakkında Açıklamalar". Maden Tetkik ve Arama Dergisi, 62: 47-58.

Grant, C. (2010). "Towards a Typology of Visitors to Geosites". The Second Global Geotourism Conference, Making Unique Landforms Understandable (April 17-20, 2010). Mulu, Sarawak, Malaysia.

Henriques, M. Helena \& Brilha, Jose (2017). UNESCO Global Geoparks: A Strategy Towards Global Understanding and Sustainability”. Episodes, 40(4): 349-355.

Hose, Thomas A. (1995). "Selling the Story of Britain's Stone". Environmental Interpretation, 10(2): 16-17.

Hose, Thomas A. (2000). Geotourism and Definitions. Oxford: Goodfellow Publishers. 
Hose, Thomas A. (2005). "Geotourism, Appreciating the Deep Time of Landscapes". Niche Tourism: Contemporary Issues, Trends and Cases. Ed. Marina Novelli. Oxford: Elsevier, 27-38.

Hose, Thomas A. (2008). "The Genesis of Geotourism and its Management Implications". $4^{\text {th }}$ International Conference, GEOTOUR 2008, Geotourism and Mining Heritage, Abstracts Volume. Krakow, 24-25.

Joseph, Scala (2006). Heraklee Du Latmos. Athens: Athens University Press. Kapluhan, Erol (2014). "Türkiye'de Turizme Bağlı Kentleşmelere Farklı Bir Örnek: Milas (Muğla)”. Uluslararası Avrasya Sosyal Bilimler Dergisi, 5(15): 120-141.

Kavecic, Mojca \& Peljhan, Martina (2010). "Geological Heritage as an Integral Part of Natural Heritage Conservation through its Sustainable Use in the Idrija Region (Slovenia)". Geoheritage, 2(3): 137-154.

Kocalar, Aziz C. (2018). "Tarihi Çevre Koruma Sorunları (Karia Devleti): Herakleia Latmos". International Journal of Social Humanities Sciences Research (JSHSR), 5(19): 654-662.

Kocalar, Aziz C. (2020). "Latmos Geopark (Beşparmak Mountains) with Herakleia Latmos Antique Harbour City and Bafa Lake Natural Park in Turkey". Turkish Journal of Engineering, 4(4): 176-182.

Koç, Yasin vd. (2019). "Yi-Fu Tuan ve Humanistik Coğrafya". Sosyal Bilimler Alanında Araştırma Makaleleri-1. Ed. İsmail Elagöz vd. Ankara: Gece Kitaplığı, 168-181.

Konuk, Koray (2005). "The Coinage of Latmos". Feldforschungen im Latmos Die karische Stadt Latmos. Berlin: Deutsches Archaologisches Institut, 54-59.

McKeever, Patrick J. and others (2010). "The UNESCO Global Network of National Geoparks". Geotourism, the Tourism of Geology and Landscape. Eds. David Newsome and Ross Dowling. Oxford: Good Fellow Publishers, 221-230.

MGM-Meteoroloji Genel Müdürlüğü (2017). Yıllık. Ankara: MGM.

Newsome, David \& Dowling, Ross K. (Eds.) (2010). Geotourism: The Tourism of Geology and Landscape. Oxford: Goodfellow Publishers.

Ólafsdóttir, Rannveig \& Tverijonaite, Edita (2018). "Geotourism: A Systematic Literature Review". Geosciences, 8(7): 234. 
Öz, Ummahan (2014). Kurukümes Dağı (Milas-Muğla) Florası. Yüksek Lisans Tezi. Muğla: Muğla Sıtkı Koçman Üniversitesi Fen Bilimleri Enstitüsü.

Peschlow, Aneliese (2011). Latmos'ta Bir Karia Kenti: Herakleia (Şehir ve Çevresi). Ankara: Homer Kitabevi.

Shcren, Hinauf (1978). Archäologische Arbeiten in der Türkei. Deutschland: Institut für Sozialwissenschaften der Universität München.

Tuan, Yi- Fu (1977). Space and Place: The Perspective of Experience. Minneapolis: University of Minnesota Press.

URL-1: https://line.17qq.com/articles/cldglgplpv.html (Access: 12.5.2014).

URL-2: "List of UNESCO Global Geoparks". http://www.unesco.org/new/ en/natural-sciences/environment/earth-sciences/unesco-globalgeoparks/list-of-unesco-global-geoparks/ (Access: 16.01.2020).

URL-3: https://blogs.faz.net/stuetzen/page/14/ (Access: 20.10.2015).

URL-4: "Introduction". http://www.europeangeoparks.org/ ?page_id=342 (Access: 26.05.2018).

Zouros, Nickolas (2010). "Lesvos Petrified Forest Geopark, Greece: Geoconservation, Geotourism and Local Development”. Journal of Parks, Protected Areas and Cultural Sites, 27: 19-28.

The following statements are made in the framework of "COPE-Code of Conduct and Best Practices Guidelines for Journal Editors":

Author's Note: This study was produced from Bekir Derinöz's PhD thesis titled "Geotourism Resources of Mugla and its Utilization Potentials".

Acknowledgment: I would like to thank my advisor Prof. Dr. Gözde Emekli, who contributed to this study with her ideas and guidance.

Ethics Committee Approval: Since the field study was conducted before 2020, between 2015 and 2018, the ethics committee approval is not required; however, research ethics were followed.

Declaration of Conflicting Interests: The author has no potential conflict of interest regarding research, authorship or publication of this article. 